\title{
Sutro's Glass Palace: The Encapsulation of Public Space
}

\author{
NEREA FELIZ \\ University of Texas at Austin
}

This paper looks at the Sutro Baths (1894-96) in San Francisco as an early example of the interiorization of public space, as a pioneer "Fun Palace" and a stage of consumption. The Sutro Baths were an encapsulated microcosms, the delirious dream of an ambitious millionaire, engineer, and later major of San Francisco. Sutro, a German immigrant and entrepreneur managed to encapsulate the ocean inside a spectacular glass palace. The history of these baths is also a reflection of the problems of social inclusion and exclusion derived from the privatization of public space. Besides being the largest interior space for bathers in the world at the time, the Sutro Baths are considered to be the first water park: a strange amalgam of pools, burgers, a taxidermy collection, a wax museum and a winter garden aspiring to the hanging gardens of Babylon. The climatized atmosphere and the ocean were sheltered, altered, domesticated and commodified: "Always as balmy and summery as mid-June...Here's is the spot to loaf in tropic comfort like a Fiji Islander. No nudist and practically no missionaries, but everything else is Number One Triple A Tropical Style!" ${ }^{1}$ Sutro inaugurated a new typology, the lineage of which portrays a history of attempts to construct autonomous spaces for immersion within altered physics that are internalized and that offer a new type of socio-natural form. Inside these hedonistic bubbles, public life is reduced to a collective leisure experience.

\section{GLASS PALACES}

Public space has gradually changed from a truly public space to a conglomeration of multiple privately owned public spaces. As Public spaces progressively become privately controlled, the last century has witnessed the progressive interiorization of public activities. The extent of this interiorization leads Sloterdijk to define the world as a "grand interior" and to consider the Crystal Palace as the turning point marking "the tendency to make both nature and culture indoor affairs." ${ }^{2}$ The "palace" designation, to name the representative space of the city of London during the Great Exhibition of 1851, was a defining moment in architecture at the time. The media related the Crystal Palace to the idea of a Palace for the People. ${ }^{3}$ Its transparency was interpreted as a call for accessibility for the entire public, and a promise of inclusive universality. For the first time, the masses could actively participate in consuming the exhibited objects. It was a new form of consumption: mostly visual. According to Peter Sloterdijk, "With its construction, the principle of the interior overstepped a critical boundary: from then on, it meant neither the middle- or upper class home nor its projection onto the sphere of urban shopping arcades; rather, it began to endow the outside world as a whole with a magical immanence transfigured by luxury and cosmopolitanism." ${ }^{\prime 4}$

The success of this formula rapidly influenced the architecture of the first department stores. Two years after the opening of the Crystal Palace, in Paris, Au Bon Marché (1853-74) emulated the transparent and volumetric vastness of Paxton's design by introducing a large "empty" atrium space. The store's elevated walkways and monumental stairs allowed visitors to visually take in the enormity of the space brimming with merchandise. The features of the palace of the people, its transparency and the monumentality of a great "void" crossed by stairs, were used at the service of mass consumption. ${ }^{5}$ The palace of consumption was emerging as a new typology. There are clear parallelisms between the Crystal Palace, the first departments stores, and the Sutro Baths (1894-96). All of them were inhabitable vitrines, recreational display windows where visitors were both an active and a passive part of the spectacle. The Sutro Baths marked a novel typological transfer: the palace of the people, the palace of consumption, and the palace of sports blended together in a megalomaniac recreational center. The facility encapsulated a portion of the San Francisco coast. The atmosphere and the sea were enclosed, altered, domesticated and commodified. Inside the Sutro Baths, nature and the visual spectacle of the human body also became objects of consumption.

Selecting and transferring the until-then novel crystal palace architectural type to a public bathing facility was particularly unusual in relation to the architecture of this typology up until this point. During this time, a romantic perspective of nature, renewed interest in physical exercise, hydrotherapy and Orientalist fascination with Turkish baths had recently marked the decisive return of public bathing practices to Europe and the US. At the opposite side of the country, the new recreational bathing facilities in New York, on the Hudson River, were increasingly popular. However, the architecture of these spaces consisted of a modest floating piece that enclosed the bathing area within. A simple one-story wooden ring box sheltered the bathers from outside gazes. The "fortress" idea behind these structures was literally visible in some of the projects that crowned the building with battlements. Considering social prudity and the standard bathing architectural types of the time, Sutro's choice of transparency was particularly revolutionary. 


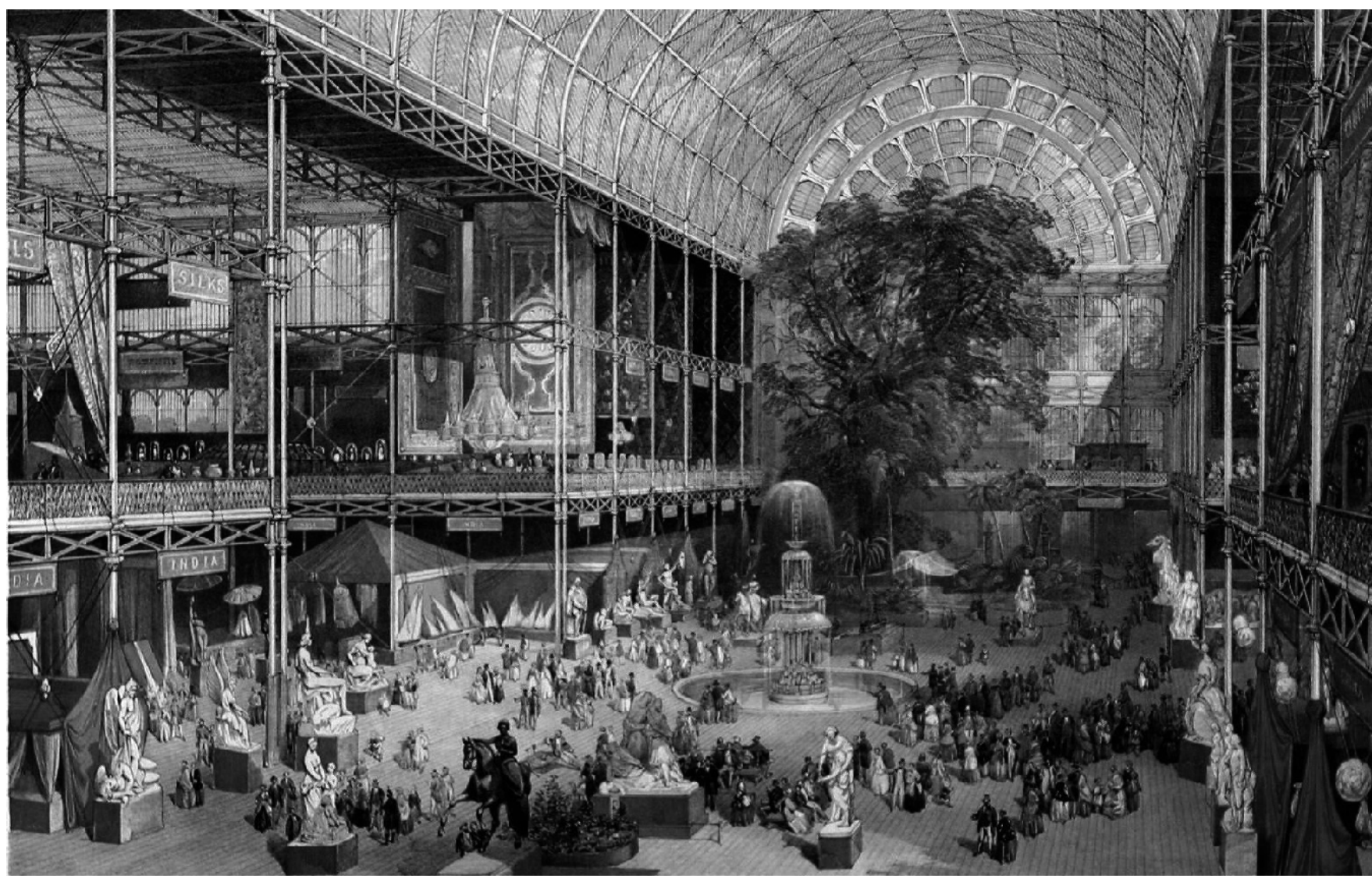

Figure 1: Crystal Palace. McNeven, J. (draughtsman (artist), William Simpson (lithographer), Ackermann \& Co. (publisher), 1851. Courtesy V\&A Museum. Collection.

\section{DOMESTICATED NATURE}

The Sutro Baths were the delirious dream of a German immigrant, entrepreneur, engineer, and later major of San Francisco. Adolf Sutro (1830-1898), managed to domesticate the ocean and lock it inside a formidable glass palace. In the late 19th century, San Francisco was eager to increase its bathing points, which at the time were limited to simple outdoor facilities in fresh-water canals. Its location next to the Pacific Ocean would have made it a privileged enclave if not for the low ocean temperatures. "There can be no doubt that a great number of our citizens would seek to enjoy the tonic effects of sea bathing, but for the low temperatures of the water."7

The location of the Sutro Baths, Point Lobos, is a promontory on San Francisco's west coast. In 1850 the San Francisco bourgeoisie began frequenting the area to spend the day at the beach. As of 1880, the adjacent Seal's Beach went from being a picturesque site, to an area of recreation for tourists and San Francisco's citizens. In 1881, Sutro purchased the Point Lobos promontory and Seal's Beach. Seven years later, Sutro announced his intention to build covered, heated pools at the base of the promontory by channeling the water of the ocean. It was the beginning of a titanic construction process that would transform the entire cove. "I must have it large, pretentious, in keeping with the environment, with the great ocean itself." ${ }^{8}$ Robert Stewart, Sutro's biographer, declared the baths Sutro's last effort to reach historical greatness. ${ }^{9}$

Using the natural tide, a series of platforms at different levels conducted the seawater to seven pools. Building the facility was a complex structural challenge. After two failed attempts to erect a dyke, three breakwaters were built robust enough to protect the structure from the ocean's current. At high tide, the tanks floodgates opened until it was filled. The system benefited from the natural slope of the terrain, progressively filling with the dammed tidewater. A parallel drainage system controlled water expulsion and the fluid volume in the seven pools.

The titanic complex was built in record time. Adolf Sutro initiated construction without an overarching design that coordinated the relative position of the multiple building structures, or provided guidelines for formal coherence. Emil S. Lemme and C.J. Colley, the architects of the scheme, had only one month to develop the proposal. ${ }^{10}$ Beyond designing the envelope, the program needed to include a Turkish bath center, several restaurants and clubs, a curiosities museum, strolling areas, a grandstand, an amphitheater for concerts, an office area, a laundry complex, dressing rooms and additional service areas. The accelerated design 
process is very apparent in the project which is a sort of eclectic macro-collage. The final design consisted of three units parallel to the coast line; two of them covered the pools, and the other the grandstand.

\section{A PROFITABLE FUN PALACE}

Announced as the largest swimming complex in the world at the time, the baths opened to the public in 1896 . The facility had capacity for 1,628 bathers and 7,400 spectators. The opulence of The Sutro Baths, with their seven heated pools impressed the citizens of San Francisco. Besides being the largest interior space for bathers anywhere at the time, the Sutro Baths are considered to be the first water park: a strange amalgam of bathing, sports, hot dogs, taxidermy collection, a wax museum and a winter garden. The natural pools were equipped with diving boards, rafts, swings, and gymnastic equipment such as rings and trapezes. The resulting spectacle was a unique combination of athletic competition, spontaneous play, acrobatic displays and curiosities, such as Professor Karl, "'the marvelous Anthropic Amphibian, who eats, drinks, smokes, writes and sleeps under water."11

The project's infrastructure was innovative. Stylistically, the project was very eclectic. Visitors entered through a loose replica of a Greek portico. ${ }^{12} \mathrm{~A}$ monumental classic staircase led them from the entry to the dressing rooms, a dizzying descent of several stories, framed on both sides by platforms with tropical plant life. While going down the stairs, visitors could view the ocean's horizon in front of them. The access sequence evoked a palatial experience for bathers. This appealing spatial feature was also commonly used in large European department stores. The result was a pseudoPiranesian space, a pioneer Fun Palace of capitalism. An amphitheater for concerts and a series of landscaped avenues hanging over the baths allowed visitors to stroll through the complex and observe the pools from different angles (providing access to the clubs and restaurants). Walking through the structure was an attraction, as visitors enjoyed the perspective of the crowd in movement. Part of the experience of consumption in the Sutro Baths was seeing and being seen, the conscious pleasure of simultaneously consuming and creating a novel metropolitan experience.

The structure was a fairly simple scaffolding open to different uses. The indeterminate quality of the space was another of the original characteristics that this project shared with the Crystal Palace. Multiple activities were offered simultaneously; "inter-accessibility" incited a feeling of free will in the visitors. The concentration of people and the visual accessibility of multiple activities stimulated consumption and the spontaneous emergence of new uses. Sutro added a museum to the complex, in his own words: "to help install in the minds of youthful visitors a desire for learning."13 The museum displayed all sorts of curiosities: trophies from Sutro's own journeys, collections of shells and marine fauna, taxidermy, wax statues and even Egyptian mummies.
The moist environment and the greenhouse effect were used to add an extraordinary winter garden for tropical plants: manguey, palm trees, magnolias and pomegranate. ${ }^{14}$ Both the collection of objects and of exotic plants were a characteristic status symbol of the Colonial spirit of the times. A collector's zeal was the manifestation of colonial power, dominion and wealth. At the same time, it was the expression of the mystification of the colonies and a nostalgia for pre-Industrial life, the exoticism of far-off natural paradises, free from modern civilization. The botanical collection sought to bring home small pieces of those virgin, untamed paradises. The intent to link the bathing experience to the myth of foreign paradisiacal cultures is apparent in some of Sutro Baths' promotional messages: "Always as balmy and summery as mid-June... Here's is the spot to loaf in tropic comfort like a Fiji Islander. No nudist and practically no missionaries, but everything else is Number One Triple A Tropical Style!"15 The combination of the monumental steel structure, the view of the ocean, the sound of the waves, swarms of people splashing, the humidity, the heat and the smell of seawater, spattered with the smell of burgers, stimulated a very unique and chaotic multi-sensory experience.

\section{SOCIAL CONDENSER}

The history of the Sutro Baths is also an early example of the problems of social inclusion and exclusion derived from the privatization of public space. Sutro was a self-interested philanthropist, whose cultural contributions to the city of San Francisco often brought him economic profit. He fought to make the baths accessible via public transportation. He publicly said: "I had intended Sutro Heights as a breathing spot for the poor people, as a benefit to the public.." ${ }^{16}$ In 1880, he funded the construction of a small railway line that would connect San Francisco's transportation network with the Baths. During this period, Sutro negotiated with Southern Pacific Railroad for a transfer from one line to another at no additional charge. After a tense negotiation period, Sutro won the dispute with the railway company. Around the same period, Sutro became mayor of San Francisco. ${ }^{17}$ In the first few years, the baths received millions of visitors. The new rail line radically increased the baths economic profit. The ease and affordability of the commute made the baths a mass leisure destination for the people of San Francisco. With the entry ticket, bathers received a towel and a bathing suit. ${ }^{18}$ Originally, everybody had to wear the same outfit in the water. Sutro expressed his desire for the bath to be a space for social integration, a place for collective encounters that temporarily eliminated socioeconomic differences.

On the other hand, the Sutro Baths were one of the first stages of racial litigation. In 1897, the civil rights "Dibble Bill" law was passed in California, making it illegal to prohibit African Americans from entering any public establishment. John Harris, a black citizen, requested access to The Sutro Baths twice, and was denied. Mr. Harris sued the establishment. The press reported this statement made by Sutro's son with respect to African Americans: "so long as they are sober and well behaved 


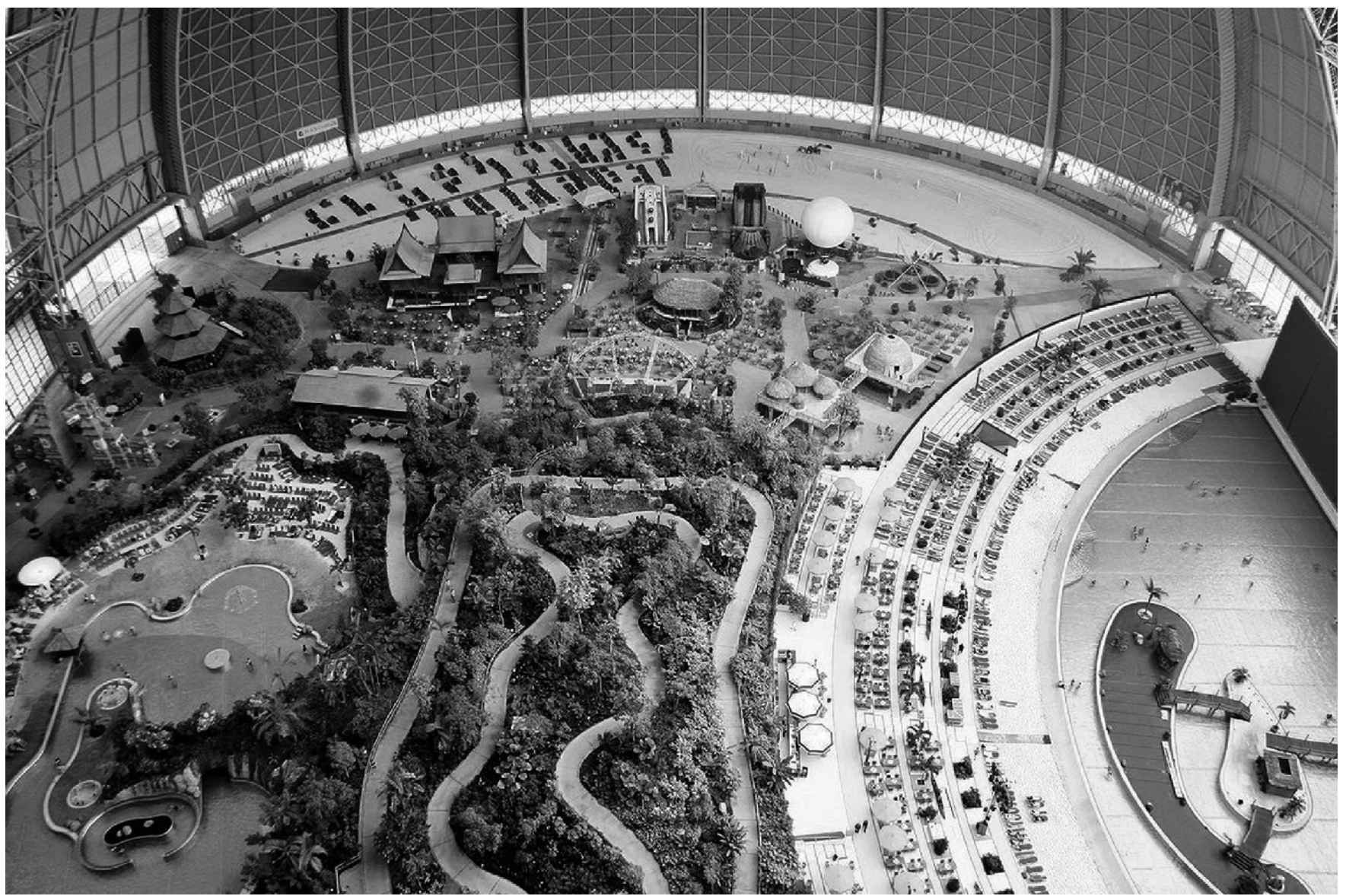

Figure 2: Tropical Islands, Berlin, 2009. Author Bmalina. Wikimedia Commons.

are allowed to enter the baths as spectators, but are not permitted to go in the water. It is not a matter of personal feeling with us but of business necessity. It would ruin our baths here because the white people would refuse to use them...No one could in equity expect us to make such a sacrifice. I do not think such a case could ever be won against us. ${ }^{19} \mathrm{Mr}$. Harris ended up winning the lawsuit. However, in the following decades pools continued to be among the sites of marked racial discrimination. With desegregation, a large part of the white population ceased going to public pools. Residential suburbs were filled with private pools and clubs where racial discrimination was possible. Many city halls stopped investing in public pools as recreational infrastructures and allowed the country's public pools to progressively deteriorate..$^{20}$ The consequences are still perceptible, white Americans are twice as likely to know how to swim as black Americans. ${ }^{21}$ The degree of shared intimacy in pools heightened racial tensions. First public pools such as the Sutro Baths were a double-edged sword of diverse socioeconomic inclusion and racial exclusion.

\section{THE HEDONISTIC BUBBLE OF THE ETERNAL SUMMER}

In 1966, the Sutro Baths burned and were completely destroyed. The cause of the fire is unknown. Today, the old concrete pools are contemporary ruins. However, Sutro inaugurated a new typology, an architectural formula to capitalize on the ludic pleasures of bathing. Throughout the 20th century, new, more refined versions of the "tropical" bubble format for aquatic parks appeared.

Seagaia Ocean Dome, in Miyazaki, Japan, bore many similarities with The Sutro Baths. Its doors were open to the public between 1993 and 2007. In 2007, it closed for reform works, but ended up remaining closed until its recent demolition in 2017. Seagaia was another gigantic ludic complex located on the other side of the Pacific Ocean, just 100 meters from the sea. Guaranteed eternal summer was its popular draw. The structure was 100 meters wide and 300 meters long, with 10,000 -person capacity. The facility had artificial waves high enough to surf, white sand, tropical vegetation, rocky islands and a volcano with episodic eruptions, 40 water slides that pushed visitors at $40 \mathrm{~km}$ per hour, a heated pool, a kids' pool and several floating pools.

Aerium, an old hangar located in Brandenburg, Germany, opened to the public in 2004 as an aquatic park. Located in Brandenburg, $50 \mathrm{~km}$ from Berlin, the hangar was built in 1992 by the company Cargo Lifter. It is the largest mono-volume interior space in the world. Cargo Lifter declared bankruptcy 
in 2002. Tanjong, a large multinational company, purchased the structure and renovated it, opening it to the public in 2004 as an aquatic park called Tropical Islands. ${ }^{22}$ According to its promotional website, the premises are organized into seven zones that match with seven exotic destinations, from Thailand to Africa. The tropical "sea," for which the leisure center is named, is the size of three Olympic pools. Tropical Islands is always at $26^{\circ} \mathrm{C}$. It includes twelve bars and restaurants, a beach, a jungle area, a lagoon, and a golf course. Inside, visitors can choose to sleep in a luxury hotel or camp. Tropical Islands offers seven different types of camping, ranging from large group tents, to tipis. Visitors can purchase a ride in a hot-air balloon inside the premises. Riding bubbles within the bubble is possible.

\section{CONCLUSION}

The lineage of this typology that started with the Sutro Baths portrays a history of attempts to construct autonomous spaces for immersion within altered physics, encapsulated portions of the world, artificial atmospheres that are internalized and independent from their surroundings. These sealed environments offer a new type of socio-natural ${ }^{23}$ form. Exhaustive mechanical control over air temperature, water and ambient humidity define these spaces. The condition that they ought to be a large mono-volume space without partitions (such as the Crystal Palace), is a fundamental trait that enables visual consumption of all the activities offered. The sight of the swarms of bathers is also an attraction. As spaces of consumption, leisure and spectacle, the true vocation of these spaces is full territorial extension. Their boundary limits, are only the manifestation of the technical limitation for climatization of the environment.

The performance of the architectural enclosure of these spaces is merely functional. Their envelope is only a climatic protection membrane, it does not serve any representational purpose. Dreams of transparency and immateriality trigger the design of these facades. They are prosthetic membranes to defend against the Nature outside. Inside, the interior structures and the furniture are heavily loaded with exotic references. Palm trees, coconut trees, thatched huts, geographical features, and ancient plastic temples occupy the space. The realism of these reproductions appears irrelevant. The most recurring themes are tropical exoticism and nostalgia for the pre-Industrial Age. In broad strokes, the contemporary imagination does not differ much from the late 19th century one. However, the technology is more refined. Ironically, the latest technologies serve the illusion of evasion to a pre-technological space. A will to immerse themselves and consciously participate in this strange blend of reality and oddness characterizes the visitors. These manufactured Eden gardens are tourist destinations. Tourists entering these spaces subscribe to play-act within a vacation mood inducing environment. ${ }^{24}$ The extensive interiorization of public activities inside privately controlled building complexes is problematic. Truly public space allows for unmediated social interaction, inside these hedonistic bubbles, public life is reduced to a collective leisure experience. ${ }^{25}$
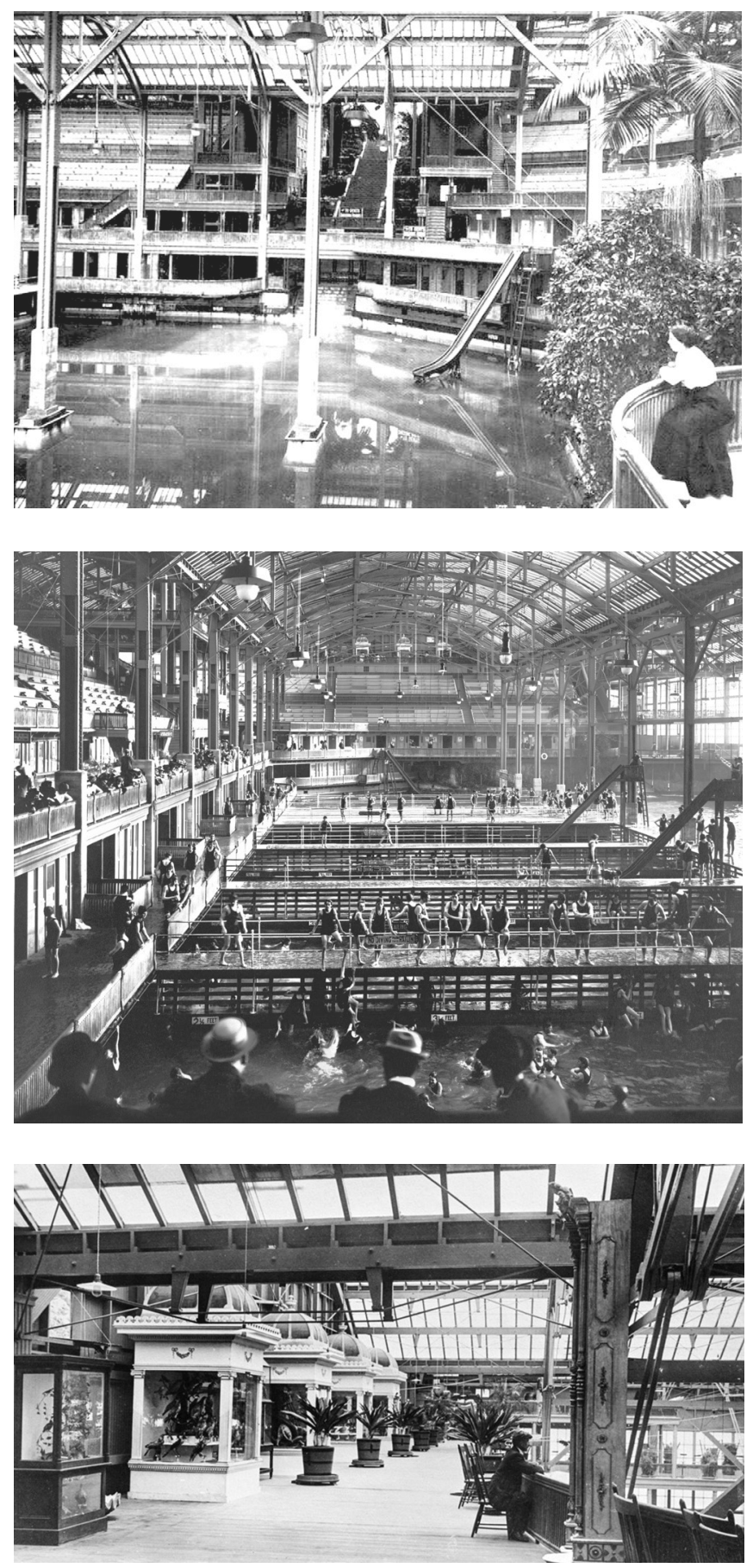

Figure3: Sutro Baths Interior Views. From top to bottom. Circa 1910. Cour- tesy Outside Lands, Western Neighborhoods Project wnp4/wnp4.0310b. From Private Collector, Martin Behrman. Figure4\&5: Courtesy Golden Gate National Recreational Area, Park Archives. San Francisco Parklands, Sutro Baths GOGA-2316. 


\section{ENDNOTES}

1. Ariel Rubissow Okamoto, A Day at the Seaside: San Francisco's Sutro Heights, Cliff House, and Sutro Baths (Golden National Parks Association, 1998) quoted in Fred Gray, Designing the Seaside, Architecture, Society and Nature (London: Reaktion Books, 2006), 196.

2. Peter Sloterdijk, En el mundo interior del capital (Madrid: Siruela, 2014).

3. Mark Pimlott, The Public Interior as Idea and Project (Netherlands: Jap Sam Books, 2016).

4. Sloterdijk, En el mundo interior del capital.

5. Pimlott, The Public Interior as Idea and Project.

6. James P. Delgado et al., "The History and Significance of the Adolph Sutro Historic District: Experts from the National Register of Historic Places," National Park Service of the United States, accessed July 12, 2018, https://

7. Delgado et al., "The History and Significance of the Adolph Sutro Historic District: Experts from the National Register of Historic Places."

8. "Saltwater Bathing for People. Grand Opening of a Superb Palace of Water" San Francisco Evening Bulletin, April 7, 1894, in "Sutro's Glass Palace, The Story of the Sutro Baths" by John A. Martini (California: Hole in the Press Bodega Bay, 2014), 43.

9. James P. Delgado, Denise Braedly, Paul M. Scolari, Stephen A.Haller. The History and Significance of the Adolph Sutro Historic District: experts from the National Resiter of Hsitoric Places.

10. Martini, John A." Sutro's Glass Palace, The Story of the Sutro Baths." (California: Hole in the press Bodega Bay, 2014), p.27,28.

11. Marilyn Blaissdell and Robert Blaissdell, San Francisciana: Photographs of Sutro Baths (San Francisco:Marilyn Blaisdell, Publisher, 1987.

12. Fred Gray, Designing the seaside, architecture, society and Nature, 196.

13. Okamoto. A day at the seaside quoted in Fred Gray, Designing the seaside, architecture, society and Nature, 196.

14. Fred Gray, Designing the seaside, architecture, society and Nature, 196.

15. Ibid, 197.

16. The History and Significance of the Adolph Sutro Historic District: experts from the National Resiter of Hsitoric Places.

17. Ibid.

18. Martini, John A."Sutro's Glass Palace, The Story of the Sutro Baths." (California: Hole in the press Bodega Bay, 2014), p.58.

19. "Negroes Claim Civil Rights," San Francisco Call, August 2, 1897, p. 5 . Quoted in LaBounty, Woody. "Sutro Baths Segregation." Ocean Beach Bületin, February 22, 2011. http://www.outsidelands.org/sutro-baths-segregation php "The Story of Floors," Armstrong Cork Co. (1959). Building Technology Heritage Library, https://archive.org/details/TheStoryOfFloors

20. See WILTSE, Jeff. Contested Waters: A Social History of Swimming Pools in America. The University of North Carolina Press, 2009.

21. Hackman, Rose. "Swimming while black, the legacy of segregated public pools ives on." The Guardian, August 4, 2015. https://www.theguardian.com/ world/2015/aug/04/black-children-swimming-drownings-segregation

22. Information about Tropical Islands Resort in Wikipedia: https://en.wikipedia. org/wiki/Tropical_Islands_Resort

23. David Gissen frames the notion of socio-natural form in: Gissen, David. Manhattan Atmospheres, Architecture, the Interior Environment and Urban Crisis. Minneapolis: University of Minnesota Press, 2014.

24. See Lee Stickells, "Swiss Cheese and Beanbags: Producing Interior Urbanism" in The Handbook of Interior Architecture and Design, ed. Graeme Brooker an Lois Weinthal (New York: Bloomsbury, 2013), Kindle.

25. Ibid. 